\title{
Social Sports Undergraduate Programs in Shandong Province
}

\author{
MA Xiao-hua \\ College of PE Taishan University ,Taian ,271021, China \\ e-mail: mxh8682067@163.com
}

Keywords:Social sports specialty; training mode; training objective; curriculum setting

\begin{abstract}
University social sports majors bear the the important task of training required talents for the development of social sports. From social sports professional training objectives, professional orientation, teacher training and source of students, Research on social sports professional personnel training mode of Shandong Province Colleges, In response to the problem, to rich educational content and highlight the school characteristics, Rebuild the curriculum system according to the social development, to explore social sports training model.
\end{abstract}

\section{Introduction}

In 1998 ,as a new professional,Social sports specialty is one of five Sports professional directory which was prescribed by the Ministry of education in"Colleges and universities undergraduate course catalog" .After ten years of exploration and development, it has begun to take shape in the country and Shandong province.

\section{The concept of social sports professional training}

Different scholars put forward the concept of talent training mode of social sports specialty from the perspective of their own research.Chen Zhangyu put forward "to meet the needs of the talent market in the new century, We must break the training mode of single talent, the subject system is the basic framework of the development of students which based on the needs of society, optimizing the structure of curriculum system, renewing teaching content, curriculum setting, strengthening humanistic quality as the basis,establish compound social sports personnel training mode of thick foundation, wide caliber, high-quality and re-innovation ability" [1]. Yang Lei proposed new concept of social body Professional Training Mode,which is " Zhi yuan line side, the high-tech pure " [2].

\section{Research methods}

We design the "social sports specialty teachers questionnaire"and "social sports specialty students questionnaire " according to the content and purpose of the research, The questionnaire adopts the closed and open combined form [3]. The survey participants are teachers and students of social sports professional in Shandong province university. In order to ensure the questionnaire has good validity and reliability,We consult the relevant social sports experts and academics in the process of formulating, and evaluate the validity of questionnaire,nine experts of twelve experts believe that the questionnaire are very effective,three experts think questionnaires effectively,no experts believe that the questionnaire is invalid.Therefore, the design of the questionnaire conforms to the standard,and test the reliability of teacher questionnaire.The correlation coefficient $\mathrm{R}=0.932$, has high reliability, meet the needs of this study.

Analysis the data using SPSS17.0 software and Excel software.

\section{The talent cultivation present situation of social sports specialty in universities of Shandong province}

Shandong University was the first university in Shandong province, which set up social sports specialty in 2002, Since then, the Shandong Sports Institute, University of Jinan and other 
universities have set up undergraduate social sports major.Thirteen colleges and universities in Shandong province have been opened undergraduate social sports major by the end of 2012,undergraduate students in school have reached thousands of people, Eight universities already have social sports graduates.

\section{A. Ttraining Objectives}

There is a big difference in training target of Social Sports Specialty in China,Such as specialized personnel, applied talents, compound talents.For example: Tian Yupu believes that in the article" The Confusion and Choice of the Education of Social Sports Major Nanjing Normal University ":Social sports specialty must closely around the social sports talent demand.Through the professional education and social sports talents knowledge structure, cultivate specialized talents for the development of thesocial sports [4].

Through TableI and TableII,Goal setting without considering the geographical characteristics of school culture in social sports professional of Shandong, as well as their professional characteristics,Some universities even cultivate professional directory objects in the direct copy of Ministry of education.

\begin{tabular}{|c|c|}
\hline University Name & Training objectives \\
\hline $\begin{array}{l}\text { Shandong Sports } \\
\text { University }\end{array}$ & $\begin{array}{l}\text { Training of senior specialized talents with the basic theory, knowledge and skills of social sports, organization and } \\
\text { management, consulting, business development and teaching research in the mass sports activities. }\end{array}$ \\
\hline $\begin{array}{l}\text { Shandong Normal } \\
\text { University }\end{array}$ & $\begin{array}{l}\text { Cultivating application-oriented talents all-round development of morality, intelligence, body, beauty, With the solid social } \\
\text { sports professional knowledge With modern sports consciousness and idea,Engaged in the organization and management } \\
\text { counseling, management and development work of mass sports activities; Also can be competent for the work of school } \\
\text { physical education, teaching, sports training, competition, talents and engaged in research work, sports science and sports } \\
\text { administrative work. }\end{array}$ \\
\hline Jinan University & $\begin{array}{l}\text { Cultivating application-oriented talents all-round development of morality, intelligence, body,With the basic theory of social } \\
\text { sports,Knowledge and skills,Organization and management, technical guidance, business development in the mass sports } \\
\text { activities. }\end{array}$ \\
\hline Ludong University & $\begin{array}{l}\text { Cultivating application-oriented talents with good moral self-cultivation and cultural quality,With a strong sense of innovation } \\
\text { and practical ability,Master of social sports on the basis of theoretical knowledge and basic skills,For physical fitness, leisure } \\
\text { and entertainment guide,And management of sport leisure and recreation industry, social physical work capacity. }\end{array}$ \\
\hline $\begin{array}{l}\text { Linyi } \\
\text { University }\end{array}$ & $\begin{array}{l}\text { Training high-quality applied talents all-round development of morality, intelligence, body, beauty, With international vision } \\
\text { and the spirit of innovation,With the solid basic social sports theory, basic knowledge, basic skills, humanities quality and } \\
\text { practice ability,Capable of organization and management, fitness guide, operation and development of sports industry and } \\
\text { sports of the school teaching and scientific research work in the mass sports activities. }\end{array}$ \\
\hline $\begin{array}{l}\text { Liaocheng } \\
\text { University }\end{array}$ & $\begin{array}{l}\text { The students mainly study the basic theory and basic knowledge of social sports,Accept professional training in social sports, } \\
\text { Master the organization, guidance, sports rehabilitation and health care and other basic skills of mass sports activities.Training } \\
\text { applied talents who hold the organization and management, rehabilitation and health care and other aspects of the work in the } \\
\text { mass sports activities sports . }\end{array}$ \\
\hline $\begin{array}{l}\text { Taishan } \\
\text { University }\end{array}$ & $\begin{array}{l}\text { Cultivating applied-skills talents, with all-round development of morality, intelligence, body, has the solid social sports } \\
\text { professional knowledge, with modern sports consciousness and idea, more comprehensive grasp of basic skills and methods of } \\
\text { social physical education, to engage in sports referee, social sports guidance of professional work in the field of social sports, } \\
\text { sports tourism, sports management etc. }\end{array}$ \\
\hline $\begin{array}{l}\text { Shandong } \\
\text { University }\end{array}$ & $\begin{array}{l}\text { The professional training compound sports expertise with good moral and cultural qualities, strong practical ability and } \\
\text { innovation consciousness, grasp the social sports basic theory knowledge and basic skills, can be competent for the sports } \\
\text { industry, sports fitness service of social physical education, and has strong ability of scientific research. }\end{array}$ \\
\hline
\end{tabular}

TABLE II.SOCIAL SPORTS PROFESSIONAL TALENT TRAINING TYPE AND SERVICE AREAS

\begin{tabular}{|c|c|c|}
\hline $\begin{array}{l}\text { University } \\
\text { Name }\end{array}$ & talent training type & talent service areas \\
\hline $\begin{array}{l}\text { Shandong } \\
\text { Sports } \\
\text { University }\end{array}$ & $\begin{array}{l}\text { Social sports instructor, sports management, sports administrat } \\
\text { ors, physical education teaching and research staff }\end{array}$ & $\begin{array}{l}\text { The school, community,administrative departments of sports, s } \\
\text { ports industry management field }\end{array}$ \\
\hline $\begin{array}{l}\text { Shandong } \\
\text { Normal } \\
\text { University }\end{array}$ & $\begin{array}{l}\text { Social sports instructor, sports management, sports administrat } \\
\text { ors }\end{array}$ & $\begin{array}{l}\text { The school,community, administrative departments of sports,sp } \\
\text { orts industry management field }\end{array}$ \\
\hline $\begin{array}{l}\text { Jinan } \\
\text { University }\end{array}$ & $\begin{array}{l}\text { Civil servants at all levels, social sports instructor, sports ma } \\
\text { nagement, sports administrators, physical education teaching a } \\
\text { nd research staff }\end{array}$ & $\begin{array}{l}\text { The school, community, administrative departments of sports,s } \\
\text { ports industry management field,Civil servants at all levels }\end{array}$ \\
\hline $\begin{array}{l}\text { Ludong } \\
\text { University }\end{array}$ & $\begin{array}{l}\text { Sports management personnel, physical education teaching an } \\
\text { d research staff }\end{array}$ & The school,sports industry management field \\
\hline $\begin{array}{l}\text { Linyi } \\
\text { University }\end{array}$ & $\begin{array}{l}\text { Social sports instructor, sports management, sports administrat } \\
\text { ion, sports teaching and research staff, sports news media sta } \\
\text { ff }\end{array}$ & $\begin{array}{l}\text { The school, the community, the sports administrative departm } \\
\text { ent, business, sports industry sports media field }\end{array}$ \\
\hline $\begin{array}{l}\text { Liaocheng } \\
\text { University }\end{array}$ & Social sports instructor, sports management personnel & $\begin{array}{l}\text { Community, administrative departments of sports, sports indus } \\
\text { try management field }\end{array}$ \\
\hline $\begin{array}{l}\text { Taishan } \\
\text { University }\end{array}$ & $\begin{array}{l}\text { Social sports instructor, sports management, sports administrat } \\
\text { ors, physical education teaching and research staff }\end{array}$ & $\begin{array}{l}\text { The school, community, administrative departments of sports, } \\
\text { sports industry management field }\end{array}$ \\
\hline $\begin{array}{l}\text { Shandong } \\
\text { University }\end{array}$ & Sports industry, sports and health services personnel & $\begin{array}{l}\text { The school, community, administrative departments of sports, } \\
\text { sports industry management field }\end{array}$ \\
\hline
\end{tabular}




\section{B. Curriculum}

There is emphasis on theory teaching, ignoring the sports skill teaching in the structure of the curriculum. The students do not have enough time to learn motor skills, resulting in poor motor skills, do not have their own advantages sports, the sports theory apply difficultly to sports practice.According to the survey,42.1\% teachers think that the curriculum structure have problem,57.9\% of the students think that the current curriculum can not meet their professional needs.Fewer elective class, generally less than 30\%, are not conducive to the development of students' personality.

\section{Professional Direction Setting}

The diversity of social sports development, university social sports majors need to set different professional direction to the development of social sports, But through the survey find that the training program did not specifically set different directions.

\section{Teacher Status}

The education and professional title structure of teacher determines the opening direction and characteristics of social sports major.Seen from Table III,The academic qualifications of Shandong Province university social sports professional teachers,Graduate students as the mainstay, accounted for $67.5 \%$, The second is the doctoral degree, accounted for $17.5 \%$, College-level education teachers are no longer the subject.

In terms of titles,Professor accounted for 22.5\%,Associate Professor accounted for 35\%, Lecturer $32.5 \%$, Assistant only $10 \%$. Thus, $\mathrm{PhD}$ teachers and senior teachers less.Table IV shows, the student are satisfied to teacher's teaching, The very satisfied is $37.5 \%$, The satisfaction is $16 \%$, The general is $24 \%$, dissatisfied is $10.5 \%$, Very dissatisfied is $12 \%$, We should be aware that there are close to $1 / 3$ student are not satisfied with teacher's teaching.

TABLE III.TEACHERS CONFIGURATION ( $\mathrm{N}=80$ )

\begin{tabular}{|c|c|c|c|c|c|c|c|}
\hline \multirow{2}{*}{ Classification } & \multicolumn{3}{|c|}{$\begin{array}{l}\text { Certificate or degree } \\
\end{array}$} & \multicolumn{4}{|c|}{ Titles } \\
\hline & Undergraduate & Master & Doctor & Teaching assistant & Lecturer & Associate Professor & Professor \\
\hline Number & 12 & 54 & 14 & 8 & 26 & 28 & 18 \\
\hline Percentage & 15 & 67.5 & 17.5 & 10 & 32.5 & 35 & 22.5 \\
\hline
\end{tabular}

TABLE IV . STUDENT SATISFACTION TO TEACHER'S TEACHING $(\mathrm{N}=200)$

\begin{tabular}{|l|c|c|c|c|c|}
\hline Classification & very satisfied & satisfied & general & \multicolumn{2}{c|}{ dissatisfied } \\
\hline Number & 75 & 32 & 48 & 21 \\
\hline Percentage & 37.5 & 16 & 24 & 24 & 10.5 \\
\hline
\end{tabular}

\section{E. Situation of Students}

Analysis of student enrollment motivation and pre-enrollment students participate in physical training time, We can see from table V, True love sports accounted for $42 \%$, Ready to engage in social sports work accounted for 5.5\%,To apply social sports professional because to apply other sports professional is difficulty, accounted for 23.5\%.From the analysis of enrollment motivation,many social sports majors after graduation are not engaged in social sports.Occupation characteristics of social sports cognition is not clear, some students have no confidence in the future of social sports .

We can see from table VI,Pre-school training time,less six months accounted for $45.5 \%$, Half to one year accounted for 30\%,More than two years accounted for $10.5 \%$,Short training time, affect the students to master the skills.

\begin{tabular}{|l|c|c|c|c|c|}
\hline Classification & love sports & Ready to engage in social sports & Swap & $\begin{array}{c}\text { Difficulty to apply other sports } \\
\text { rofessional }\end{array}$ & \begin{tabular}{c} 
Other reasons \\
\hline Number
\end{tabular} \\
\hline Percentage & 44 & 11 & 5 & 53 & 23.5 \\
\hline
\end{tabular}

TABLE VI. PRE-ENROLLMENT TRAINING TIME $(\mathrm{N}=200)$

\begin{tabular}{|l|l|l|l|l|l|}
\hline Classification & Less three months & Three to six months & Six months to a year & One to two years & More than two years \\
\hline Number & 34 & 57 & 60 & 28 & 21 \\
\hline Percentage & 17 & 28.5 & 30 & 14 & 10.5 \\
\hline
\end{tabular}




\section{F. The Understanding of Social Sports}

The understanding of social sports,Mainly including Table VII the understanding of the social sports work,Table VIII the understanding of the status of social sports instructor,Table IX the attitude of the students' future career.

TABLE VII . THE UNDERSTANDING OF THE SOCIAL SPORTS WORK $(\mathrm{N}=200)$

\begin{tabular}{|l|c|c|c|c|}
\hline Classification & unimportant & more important & very important & 61 \\
\hline Number & 11 & 92 & 36 & 30.5 \\
\hline Percentage & 5.5 & 46 & 18 \\
\hline
\end{tabular}

TABLE VIII . THE UNDERSTANDING OF THE STATUS OF SOCIAL SPORTS INSTRUCTOR $(\mathrm{N}=200)$

\begin{tabular}{|l|c|c|c|c|}
\hline Classification & Classification & unimportant & more important & 45 \\
\hline Number & 14 & 78 & 63 \\
\hline Percentage & 7 & 39 & 22.5 & 31.5 \\
\hline
\end{tabular}

TABLE IX . THE ATTITUDE OF THE STUDENTS' FUTURE CAREER（N=200）

\begin{tabular}{|l|c|c|c|c|c|}
\hline \multirow{2}{*}{ Classification } & Love and ready to engage in social sports work & Do not like, it may be diverted & Do not like, planning to change & Diverted & Other \\
\hline Number & 61 & 48 & 21 & 30 \\
\hline Percentage & 30.5 & 24 & 10.5 & 40 \\
\hline
\end{tabular}

The results show,Although the majority of the students think that social sports job is good,But more than half of students professional knowledge reserves are inadequate,lack of confidence and ideological instability .

\section{Suggestions}

Characteristics and the basic needs of social sports development as the guiding ideology, promoting the development of social sports specialty as the basic motive,Grasp the basic characteristics of social sports specialty,Establishing its own professional characteristics.Training objectives should meet the needs of fitness guidance and sports industry development,Re-set curriculum system in order to meet the demand of the market.

\section{Acknowledgement}

In this paper, the research was sponsored by the Taishan University teaching reform project (Project No.201026).

\section{References}

[1] Chen Zhang Yu.Studyon the Specialty Design and Curriculum Development of Social Sport in Colleges and Universities in China.[J]. Journal of Beijing Sport University, 2006, 29 (9) 1262-1264.

[2] Yang Lei.Thinking About Social Sports Humanities Quality Education Personnel Training Model.[J].Journal of X ianning University, 2008 (3) 158.

[3] Li Zheng Rong.Social sports specialty course system of Wuhan Institute of P.E.[J]. Journal of Wuhan Institute of Physical Education, 2006, 40 (3) 103.

[4] Tian Yu Pu.The Confusion and Choice of the Education of Social Sports Major Nanjing Normal University.[J].Journal of Sports and Science, 2009. 30 (6) 69. 